\title{
Customisation with crossed-basis sub-segmentation
}

Received (in revised form): 12th July, 2006

\section{Edward C. Malthouse}

is an associate professor of Integrated Marketing Communications at the Medill School of Journalism at Northwestern University. $\mathrm{He}$ is the co-editor of the Journal of Integrated Marketing and carries out research on database marketing and media management problems. He teaches marketing research, data mining, and media marketing courses to masters students and executives at Northwestern University as well as other universities around the world including. He received his PhD in computational statistics from Northwestern University, an MSc in operational research from Southampton University, and a BA in mathematics from Augustana College.

\section{Ralf Elsner}

is Vice President of the Rhenania Group. He also works for the Deutsche Post World Net as a consultant. His research focuses on direct and database marketing optimisation. He received his PhD in marketing from WHU - Otto Beisheim School of Management, Germany and a Master of Science in Economics from the University of Bonn, Germany.

\section{Keywords customer segmentation, customisation}

Abstract The paper proposes a cost-effective method of creating customised marketing contacts, and tests the method with a large field experiment. The firm should sub-segment its customers in different ways using complementary basis variables, and create marketing contacts that are comprised of content determined by the various subsegments. A field experiment illustrates and evaluates our approach, showing that customisation improves response rates, but not basket sizes. The paper also tests the 'labelling hypothesis' for newer customers, which asserts that the firm is better off guessing (labelling) the segment membership of a newer customer (about whom little is known because of limited transaction history) than sending a generic offer. We find that customised offers outperform generic offers for newer customers.

Journal of Database Marketing \& Customer Strategy Management (2006) 14, 40-50.

doi:10.1057/palgrave.dbm.3250035

Edward C. Malthouse Integrated Marketing Communications, Northwestern University, 1845 Sheridan Road, Evanston, IL 60208-2175 US

Tel: 847467 3376; Fax: 8474915925 ; e-mail ecm@northwestern. edu

\section{INTRODUCTION}

Many organisations in different industries maintain large databases that record the behaviour of their customers, and have installed customer relationship management (CRM) systems. Databases and CRM systems give organisations fine control over marketing contacts that are made with specific customers, such as direct mail pieces, e-mails, customised web pages (when the user's identity is known through cookies, logins, etc), telephone calls, and text messages. We shall refer to marketing contact points that are targeted at specific individuals or households as direct contacts. This fine control enables firms to customise marketing contacts, towards achieving some goal such as increasing response rates, spending levels, etc. The challenge to marketers is to engineer and coordinate these contacts to achieve such objectives.

There are two general approaches towards increasing response rates and/or spending levels. One is to improve the targeting of offers with scoring models. There are numerous data mining packages on the market that implement years or research on topics such as regression models, trees, 
neural networks, etc. Scoring models improve the targeting of an offer by enabling firms to select customers who are more likely to respond or spend more. The second approach, extended by this present paper, is to improve the relevance of the offer through customisation — modifying contact points to satisfy the wants and needs of customers more closely. In practice, many contacts are irrelevant and even annoying, which explains the recent success of products and services such as the do-notcall list, e-mail spam filters, caller ID, popup blockers, and digital video recorders.

There are two general approaches to customisation: recommendation agents and sub-segmentation. The recommendations made by companies such as Amazon are a well-known example of the former; ${ }^{1}$ gives a recent literature review of the algorithms. This research extends the latter approach, also known as 'customer' or 'database' segmentation, ${ }^{2-4}$ which involves partitioning an organisation's database into segments and developing different marketing contacts for each group. Malthouse ${ }^{5}$ distinguishes between market segmentation and subsegmentation - further segmentation of a firm's customers, which often come from a single market segment.

An issue that arises with either the recommendation agent or sub-segmentation approach is whether to customise contacts for new customers, about whom little is known. Companies generally know more about the preferences and tastes of longterm customers than newer ones, because they observe more transactions, browsing, etc. over time. Consequently, the chance of customising in an irrelevant way will generally be higher for newer customers than more established ones. When designing contacts for newer customers, a company can either send a generic recommendation with broad appeal, or take a guess at more specific preferences. Simonson ${ }^{6}$ develops a conceptual framework for customisation and proposes, but does not test, several research hypotheses including the customised label effect

H1: When customers do not have welldefined preferences, labelling the customer, that is, taking a guess at specific preferences, should have a positive effect when the customer trusts the company (pp. 35-36).

This suggests firms that are trusted by their customers should attempt specific customisation for newer customer rather than making more generic contacts. We evaluate this hypothesis.

The contributions of this paper are (1) to extend the sub-segmentation approaches with our cross-basis approach, (2) to illustrate and test our customisation approach with a field experiment, and (3) to evaluate empirically whether a firm should send a customised or generic contact to newer customers. Despite the widespread use of subsegmentation in practice, this is the first paper that reports results from a rigorous, large field experiment in the academic literature to our knowledge. Before we define the cross-basis approach, the next section describes the subsegmentation approach in detail and identifies its limitations.

\section{SUB-SEGMENTATION}

The cross-basis sub-segmentation approach entails (1) partitioning a customer database in at least two different ways, and (2) developing contacts for all combinations of the sub-segments. To facilitate the first step in this process, this section discusses some different sets of variables that can be used in defining sub-segments. There are many ways that a company can choose to sub-segment its customers. A sub-segmentation is useful if the company can develop contacts targeted at the sub-segments that will perform better than a one-size-fits-all contact. We now discuss several ways that are usually good ways to define sub-segments. 


\section{RFM sub-segmentations}

One way of sub-segmenting customers is to use recency, frequency, and monetary value (RFM). Recency is the length of time since the most recent purchase and is useful because it indicates whether a customer has 'lapsed.' For example, someone in an airline's 'frequent-flyer' database who has not flown with that airline in two years (recency $=2$ years) will require different contacts than someone who has flown recently. Frequency is the number of previous purchases and is a good measure of behavioural loyalty - the more often a customer has purchased from a company, the more loyal the customer is in terms of behaviour. A first-time customer (frequency $=1$ ) often requires different contacts than 'regular' ones. Monetary value, the amount that a customer has spent with a company in the past, is another indicator of behavioural loyalty.

It is important for a company to consider RFM when customising contacts, but it should not stop there. RFM alone provides very limited opportunities to achieve relevance. It is usually necessary to define sub-segments based on other variables as well.

\section{Sub-segmentations based on previous-purchase categories}

Organisations first develop measurement 'scales' indicating how much the customer buys various categories of items and defines sub-segments using these purchase category scales. For example, the Tesco supermarket chain has developed scales measuring a customer's purchases of various types of food. The 'Adventurous' scale measures the extent to which a customer (in the UK) buys adventurous food items such as extra virgin olive oil or the ingredients for Malaysian curries (Humby and Hunt ${ }^{2}$, p. 156). The 'Fresh' scale measures the extent to which a consumer buys ingredients such as fresh fruits and vegetables. The 'Prepared Food' scale measures whether customers buy items that are ready to be eaten immediately after purchase. Such scales are clustered to find sub-segments. As a second example, hotels and airlines can develop scales measuring international and domestic trips. Product category sub-segments complement RFM by enabling more relevant offers. Offers can be customised for a ready-to-eat buyer or international traveller.

\section{THE CROSSED-BASIS APPROACH TO SUB-SEGMENTATION}

The previous section identified two actionable bases that complement each other. The strengths and weaknesses of the other two bases are opposite those of the RFM approach. Our crossed-basis approach is useful whenever a firm has two or more complementary, actionable bases.

The crossed-basis approach produces a unique contact for every combination of sub-segments in a cost-effective way. It is most easily understood with an example. Consider sending a direct mail letter to customers. Suppose that the introduction is determined by RFM sub-segments. Recent first-time customers are thanked for their purchase and told about company. Recent multi-timers are thanked for their loyalty and told about certain benefits available to a heavy user. Lapsed customers receive a different introduction. Suppose further that the firm wants to offer specific product recommendations and highlight different aspects of the brand based on a customer's previous purchases. The letter would thus have the following format:

Dear [Name],

[Introduction determined by RFM sub-segment]

[Branding message based on previous-

purchase sub-segment]

[Cross-sell recommendations based on

previous-purchase sub-segment]

[Universal closing]

Implementing this customisation requires writing one introduction for each RFM 
sub-segment and one branding message and recommendation section for each previouspurchase sub-segment. An alternative would be to develop sub-segments using both the RFM and previous-purchase variables simultaneously in the cluster analysis. The problem with the latter approach is that the number of sub-segments would be large. Suppose that there are four RFM segments and eight previous-purchase sub-segments. The cross-based approach calls for writing $4+8=12$ separate insertions. The latter approach would require $4 \times 8=32$ separate versions, which would require substantial additional work and increase costs. The savings become even larger when more bases are crossed.

\section{EMPIRICAL EVALUATION}

We illustrate and test our approach with an example. A German company sells overstock books, music, and movies directly to consumers. It mails catalogues and maintains a website, with most sales from catalogue orders. This example shows how to create sub-segments using RFM and previous-purchase categories, and design customised cover letters. Cover letters are a simple and inexpensive way to test customisation; of course, more elaborate customisation is possible. Three empirical evaluations test the customised letter versus a generic letter (control group) and the labelling hypothesis using a sample from the company's database.

\section{Recency-frequency sub-segmentation}

The following four sub-segments will deter mine the introduction in our cover letter:

(1) Active first-timers: recency $<1$ year and frequency $=1$

(2) Active multi-timers: recency $<1$ year and frequency $>1$

(3) Recently lapsed: 1 recency $\leqslant 2$ years

(4) Long-term lapsed: recency $>2$ years.

\section{Previous-purchase-category sub-segmentation}

These sub-segments, which will determine a short branding message and specific crossselling items, are developed with a two-step process. The first step identifies 'interest scales' with factor analysis and the second step finds sub-segments by applying cluster analysis to the interest scales. An important difference between our approach and what is commonly done to develop market segments is that we use behavioural data rather than data from surveys. Behavioural data are more difficult to analyse because of extreme skewness and outliers. The technical details of our analysis are available on the first author's website and are summarised briefly below.

\section{Interest scale development}

This step produces a set of scales that measure a customer's interest in various types of books. The company classifies its merchandise into 67 categories such as 'romance novels,' 'crime stories,' 'jazz music,' and 'modern history books.' Counts of the number of times a customer bought something from each of these 67 categories were factor analysed, producing in the following interest scales:

(1) Science: Books on physics, science, astronomy, mathematics, biology, geology, and chemistry.

(2) History: Contemporary and general history books.

(3) Serious movies: Classics, international, German, World War I and II, and other history movies.

(4) Home and Living: Books on hobbies, health, nature, animals, plants, cooking, and self-help.

(5) Non-fiction: 'How-to' books for selfteaching, encyclopaedias, and books on economics, computers, and politics.

(6) Humanities: Books on religion, philosophy, esotericism, and psychology. 
(7) Fiction and literature: General fiction, classics, cartoons, poetry, linguistics, mythology, and audios books.

(8) Classical music: Classical music CDs and cassettes.

(9) Popular music: German hit songs, ethnic music (eg gypsy, African, or Jewish music), pop/rock, folk music, French chanson, and jazz.

(10) Pop Fiction: Crime stories, thrillers, novels, romances.

(11) Art: Books on art, artists, architecture and design, 'plates' (books where pictures and images dominate the copy), and facsimile (faithful re-creation of the original to the extent that it is virtually indistinguishable from the original copy).

(12) Sexuality: Books and DVDs about sexuality.

\section{Cluster analysis}

This step applies $k$-means clustering to the 12 interest score factors. Before we could do this, however, we had to decide which observations should be clustered. This company has very little information about the preferences of a first-time buyer who has purchased only one book. Conversely, it knows much about the preferences of someone who has purchased 50 books. We do not want to include customers in the analysis if the company has not interacted with them sufficiently to have a good sense of their tastes and therefore use only customers who purchased six or more distinct items in the cluster analysis itself (see discussion of technical details on first author's website).

Table 1 gives clusters sizes and Figure 1 shows the cluster means on the 12 interest scores used in the cluster analysis after taking the logarithm to reduce skewness. Figure 1 has seven panels, one for each cluster. A dot at the value 0 indicates that a cluster does not buy any books from a category. For example, the lower right panel shows the profile for cluster 1 ('Mostly Music'). The mean for Science is 0.05, and, accordingly, the dot for Science is close to 0 . The dot for Classical Music extends about halfway across, indicating that members of this cluster have a strong interest in classical music. It also buys some books on History, Home and Living, Popular Music, Humanities, Non-fiction, and Sexuality. Cluster 2 ('Heavy All') has average interest scores that are all above 0 and that are greater than any other cluster.

\section{Cross-basis sub-segmentation}

The crossed-basis approach calls for crossing at least two sub-segmentations. Table 1 shows a cross-tabulation of the previouspurchase-category and recency-frequency

Table 1: Relationship between interest and RF segment for customers who have purchased 6 or more distinct items in the past

\begin{tabular}{|c|c|c|c|c|c|c|}
\hline & $\begin{array}{l}\text { Recent } \\
\text { first-timers }\end{array}$ & $\begin{array}{l}\text { Recent } \\
\text { multi-timers }\end{array}$ & $\begin{array}{l}\text { Recently } \\
\text { lapsed }\end{array}$ & $\begin{array}{l}\text { Long-term } \\
\text { lapsed }\end{array}$ & Total & Per cent \\
\hline 1 Mostly Music & 389 & 5,825 & 2,162 & 1,927 & 10,303 & 8.04 \\
\hline 2 Heavy All & 20 & 4,882 & 561 & 200 & 5,663 & 4.42 \\
\hline 3 Mostly Sexuality & 1,238 & 10,707 & 4,229 & 3,320 & 19,494 & 15.22 \\
\hline 4 Mostly History & 1,409 & 15,984 & 6,616 & 7,459 & 31,468 & 24.57 \\
\hline $\begin{array}{l}5 \text { History, Home, } \\
\text { Humanities }\end{array}$ & 215 & 11,645 & 2,826 & 1,648 & 16,334 & 12.75 \\
\hline 6 Low Interests & 2,779 & 13,536 & 7,735 & 12,003 & 36,053 & 28.15 \\
\hline $\begin{array}{l}7 \text { Classical music } \\
\text { and history }\end{array}$ & 113 & 6,530 & 1,432 & 706 & 8,781 & 6.86 \\
\hline Total & 6,163 & 69,109 & 25,561 & 27,263 & 128,096 & \\
\hline Per cent & 4.81 & 53.95 & 19.95 & 21.28 & & \\
\hline
\end{tabular}




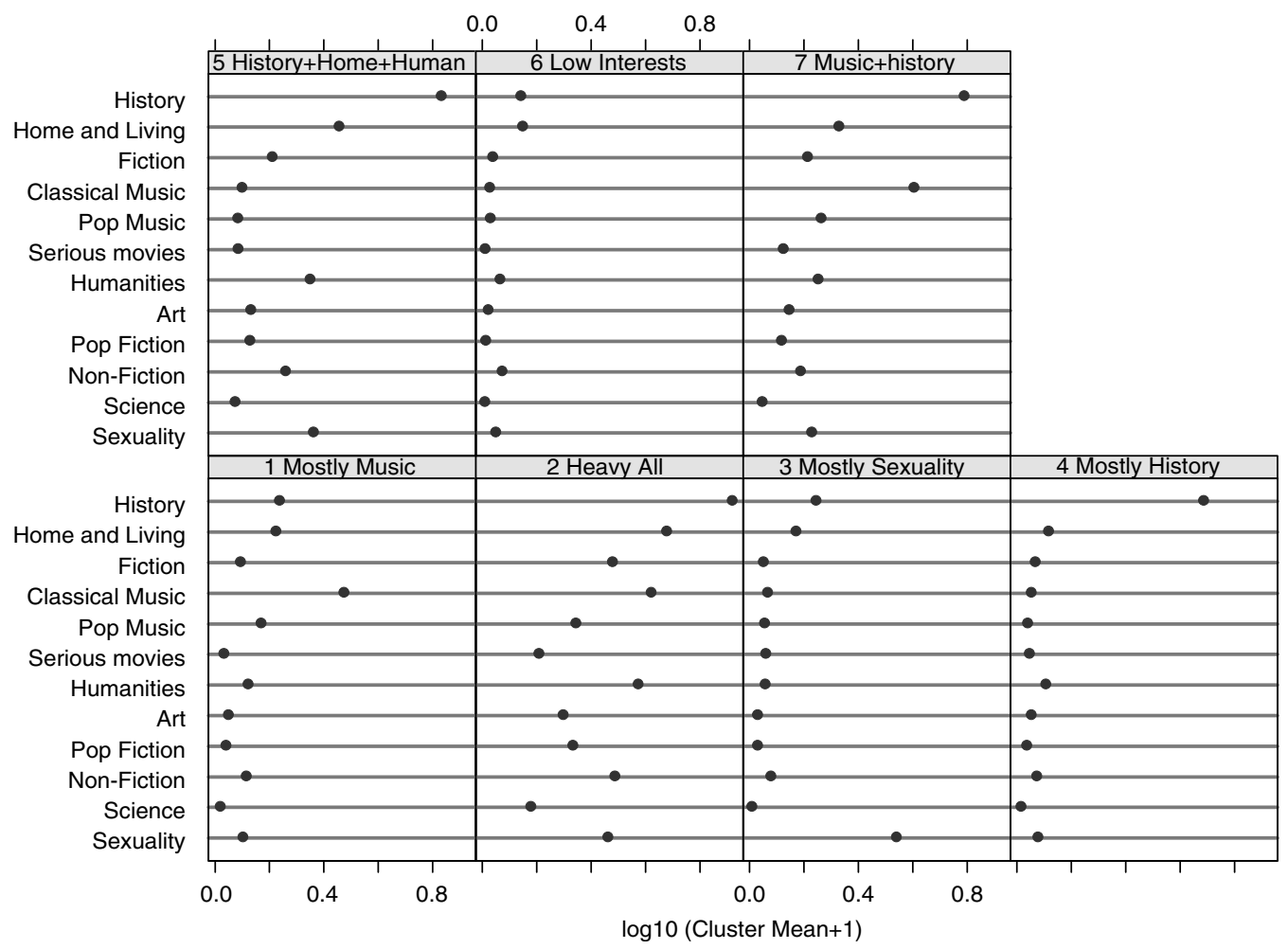

Figure 1: Cluster means of previous-purchase-category sub-segmentation

subsegmentations. Each of the $4 \times 7=28$ cells will receive a different cover letter version, with the introduction determined by recency-frequency and the branding message and recommendations determined by the previous-purchase-category subsegment.

\section{EXPERIMENTAL DESIGN AND RESULTS}

Three randomised controlled experiments evaluate the hypotheses on a catalogue mailed 14th September 2004. Every copy of this catalogue had a cover letter. Some cover letters were customised (treatment group) and others were not (the control group). Customers were assigned to the treatment (customised) or control letter at random.

There were seven different bodies containing a branding message and product recommendations. The branding message for the 'Mostly History' cluster discussed how the company has long specialised in overstock scholarly history books and the recommendations featured several history titles. The branding message for the "Mostly Music' cluster told customers that the company has recently expanded its music selection and that they have buyers devoted to finding overstock CDs from well-known artists at a favourable price. The control letter thanked customers for their business and made generic recommendations of top selling items. The overstock theme is an important part of the overall brand and is emphasised in both messages.

All tests of response rates are evaluated using logistic regression. See the first author's website for modelling details, and additional analyses of the average order amount and basket size, which were unaffected by customisation in these experiments.

Experiment one studies the effect of customisation on customers who have 
Table 2: Sample sizes for Experiment One, all customers who purchased six or more distinct items in the past

\begin{tabular}{|c|c|c|c|c|c|}
\hline & $\begin{array}{l}\text { Body } \\
\text { description }\end{array}$ & $\begin{array}{l}\text { Recent } \\
\text { first-timers }\end{array}$ & $\begin{array}{l}\text { Recent } \\
\text { multi-timers }\end{array}$ & $\begin{array}{l}\text { Recently } \\
\text { lapsed }\end{array}$ & $\begin{array}{l}\text { Long-term } \\
\text { lapsed }\end{array}$ \\
\hline 1 Mostly Music & $\begin{array}{l}\text { Body } 1 \\
\text { Control }\end{array}$ & $\begin{array}{l}705 \\
675\end{array}$ & $\begin{array}{l}2,384 \\
2,378\end{array}$ & $\begin{array}{l}1,045 \\
1,144\end{array}$ & $\begin{array}{r}1,010 \\
947\end{array}$ \\
\hline 2 Heavy All & $\begin{array}{l}\text { Body } 2 \\
\text { Control }\end{array}$ & $\begin{array}{l}119 \\
122\end{array}$ & $\begin{array}{l}2,341 \\
2,294\end{array}$ & $\begin{array}{l}287 \\
287\end{array}$ & $\begin{array}{r}95 \\
110\end{array}$ \\
\hline 3 Mostly Sexuality & $\begin{array}{l}\text { Body } 3 \\
\text { Control }\end{array}$ & $\begin{array}{l}1,378 \\
1,556\end{array}$ & $\begin{array}{l}4,451 \\
4,392\end{array}$ & $\begin{array}{l}2,102 \\
2,145\end{array}$ & $\begin{array}{l}1,732 \\
1,605\end{array}$ \\
\hline 4 Mostly History & $\begin{array}{l}\text { Body } 4 \\
\text { Control }\end{array}$ & $\begin{array}{l}2,102 \\
2,225\end{array}$ & $\begin{array}{l}6,443 \\
6,418\end{array}$ & $\begin{array}{l}3,260 \\
3,415\end{array}$ & $\begin{array}{l}3,813 \\
3,741\end{array}$ \\
\hline 5 History, Home, Humanities & $\begin{array}{l}\text { Body } 5 \\
\text { Control }\end{array}$ & $\begin{array}{l}700 \\
763\end{array}$ & $\begin{array}{l}5,205 \\
5,097\end{array}$ & $\begin{array}{l}1,364 \\
1,509\end{array}$ & $\begin{array}{l}822 \\
849\end{array}$ \\
\hline 6 Low Interests & $\begin{array}{l}\text { Body } 6 \\
\text { Control }\end{array}$ & $\begin{array}{l}1,991 \\
2,212\end{array}$ & $\begin{array}{l}3,289 \\
3,338\end{array}$ & $\begin{array}{l}2,559 \\
2,605\end{array}$ & $\begin{array}{l}4,044 \\
4,121\end{array}$ \\
\hline 7 Classical music and history & $\begin{array}{l}\text { Body } 7 \\
\text { Control }\end{array}$ & $\begin{array}{l}344 \\
412\end{array}$ & $\begin{array}{l}2,895 \\
2,950\end{array}$ & $\begin{array}{l}723 \\
723\end{array}$ & $\begin{array}{l}366 \\
360\end{array}$ \\
\hline
\end{tabular}

Table 3: Contrast estimates for interaction between treatment/control and RF segment. Response is the dependent variable and the universe is Study 1, all people who have purchased six or more distinct items in the past

\begin{tabular}{lllll}
\hline RF Segment & Estimate & Std Err & $\boldsymbol{p}$-Value & Odds $(\exp (\beta))$ \\
\hline 1. $F=1, R<1$ & 0.2035 & 0.0834 & 0.0147 & 1.23 \\
2. $F>1, F<1$ & 0.0640 & 0.0904 & 0.4794 & 1.07 \\
3. $1<R \leqslant 2$ & 0.0477 & 0.0332 & 0.1500 & 1.05 \\
4. $R \geqslant 2$ & 0.4294 & 0.1240 & 0.0005 & 1.54 \\
\hline
\end{tabular}

purchased six or more distinct items, and thus can be assigned to a customisation with 'good' reliability. There are 96,601 customers in this universe, and Table 2 shows the sample sizes for each cell in this test. Model-selection details are on the first author's website. The final model had a significant interaction $(P=0.0108)$ between RF segment and treatment/control, so we estimated the contrasts reported in Table 3 comparing treatment and control within each RF segment. The customised letter significantly outperforms the control letter in the first and fourth RF segments. The estimate for RF segment 4 (recency $\geqslant 2$ years) is 0.4294 , which is the difference between the parameter estimates for those in segment 4 who received the treatment and those in segment 4 who received the control. The odds ratio for RF segment 4 $\left(1.54=e^{0.4294}\right)$ indicates that the odds of responding for those who received the customised letter are 1.54 times greater than those who received the control. Since the interaction between interest segment and treatment is not significant, this conclusion applied to all six interest segments. Likewise, the odds of responding for those in RF segment 1 (frequency $=1$, recency $<1$ year) who received the customised letter are $1.23=e^{0.2035}$ times compared to that in RF segment 1 who received the control. The signs of the contrasts in the other two segments indicate that the treatment outperformed the control, but these differences were not significant.

Experiment Two examines a related question concerning how much customer information a firm needs to customise offers: when a firm has very little information about a customer, should the firm take its best guess at the customer's 
sub-segment membership (and which customised contact to make), or should it not try to assign such customers to subsegments (and send one-size-fits-all contacts)? For example, suppose that a customer has placed one previous order, which consisted of a single history book. Should the company assign this customer to the Mostly History sub-segment, ensuring that the customer will receive contacts extolling the extensive history selection, or should it send less specific contacts, emphasising, that is, the breadth of its offerings? If the customer is, in fact, someone who is primarily interested in history, then the Mostly History contact should outperform a generic one.

Alternatively, if the customer is misclassified, then the Mostly History contact could conceivably perform worse than a generic one. The labelling effect discussed in Simonson ${ }^{6}$ suggests that the history contact is preferred.

Experiment Two randomly assigns the 2,223 customers who have purchased fewer than six distinct items to either the treatment (customised) or control offer. The cell sizes are provided in Table 4. Note that none of the customers with fewer than six distinct items are assigned to clusters (1), (5), or (7).

The model selection process is discussed in detail in the technical report on the first author's website. The final model had the main effects for RF segment $(p<0.0001)$ and treatment $(p=0.0410)$, without any significant interactions between segments and treatment. The parameter estimate for the treatment dummy is 0.4143 , indicating that the odds of responding for those who receive the customised version are $1.51=e^{0.4143}$ times greater than for those who received the control letter. This conclusion holds across all segments, because none of the interactions with treatment were significant. These results suggest that this company should send a customised contact to customers with little previouspurchase history. These conclusions support the labelling hypothesis.

Experiment Three studies customers who have purchased six or more distinct items and are in the 'Low Interests' segment. The interests of this segment are not very distinctive and it is difficult to write a 'branding message' that will connect with this group to the same extent as, for example, the Mostly History group. The branding message could not be as specific as the others. While members of the 'Low Interest' group might have distinctive tastes, these tastes are not revealed in their purchases to date. The segment is thus similar to those analysed in Experiment Two, who had purchased fewer than six distinct items, and we ask a similar research question: should the company send a more generic (Low Interest) branding message, or should it guess at a more distinctive message?

In total, there were 35,970 customers assigned to the Low Interest segment who had purchased six or more distinct items. These customers were randomly assigned to one of three experimental groups: the control $(n=12,276)$, the 'Low Interest' branding message $(n=11,883)$, and the 'Second Best' branding message $(n=11,811)$.

Table 4: Sample sizes for experiment two, all customers who purchased fewer than six distinct items in the past

\begin{tabular}{|c|c|c|c|c|c|c|c|c|}
\hline & \multicolumn{2}{|c|}{$F=1, R<1$} & \multicolumn{2}{|c|}{$F>1, F<1$} & \multicolumn{2}{|c|}{$1<R \leqslant 2$} & \multicolumn{2}{|l|}{$R \geqslant 2$} \\
\hline & Cont & Tx & Cont & Tx & Cont & Tx & Cont & Tx \\
\hline 1. Mostly Music & 83 & 87 & 65 & 39 & 87 & 118 & 68 & 55 \\
\hline 3. Mostly Sexuality & 302 & 299 & 133 & 127 & 207 & 186 & 176 & 173 \\
\hline 4. Mostly History & 201 & 233 & 173 & 174 & 177 & 182 & 226 & 255 \\
\hline
\end{tabular}


Table 5: Sample sizes for Experiment Three, all customers who purchased six or more distinct items in the past and are assigned to the 'Low Interest' segment

\begin{tabular}{|c|c|c|c|c|}
\hline \multirow[t]{2}{*}{ RF segment } & \multicolumn{4}{|c|}{ Branding message } \\
\hline & Control & Low Interest & Second Best & Total \\
\hline 1. $\mathrm{F}=1, R<1$ & 2,212 & 1,991 & 1,930 & 6,133 \\
\hline 2. $F>1, F<1$ & 3,338 & 3,289 & 3,358 & 9,985 \\
\hline 3. $1<R \leqslant 2$ & 2,605 & 2,559 & 2,557 & 7,721 \\
\hline 4. $R \geqslant 2$ & 5,232 & 4,044 & 3,966 & 12,131 \\
\hline Total & 12,276 & 11,883 & 11,811 & 35,970 \\
\hline
\end{tabular}

Table 6: Contrast estimates for Experiment Three, comparing those who received the control, Low Interest, and Second-Best branding message

\begin{tabular}{lllll}
\hline Contrast & Estimate & Odds & Std Err & p-Value \\
\hline Second Bestcontrol & 0.1690 & 1.18 & 0.0752 & 0.0245 \\
Low Interest-control & 0.1711 & 1.19 & 0.0751 & 0.0228 \\
Low Interest-Second Best & 0.0021 & 1.00 & 0.0728 & 0.9771 \\
\hline
\end{tabular}

Experiment One analysed the 12,276 who received the control offer and the 11,883 who received the 'Low Interest' offer. In addition, the remaining 11,811 customers were sent the offer for the second-closest segment in terms of Euclidean distance. That is, we calculated the distance between each observation and the seven cluster centroids; the 'best' cluster assignment, which was the K-means cluster assignment, was the cluster with the nearest centroid and the 'Second Best' cluster assignment was one with the second closest centroid. These three experimental treatments were crossed with the RF segments, with the resulting cell sizes shown in Table 5 .

Our model selection was as follows. The first model had the two-way interaction between branding message and RF segment and the main effects. The interaction was not significant $(p=0.5457)$ and was dropped. The second model had only the main effects. Branding message was significant $(p=0.0330)$ as was RF segment $(p<0.0001)$.

We estimated contrasts to understand differences between branding messages, with the results shown in Table 6. The Low Interest and Second Best branding messages are not significantly different from each other, but both outperform the control. The odds of response for someone receiving the Second Best message are 1.18 times compared to that of someone receiving the control. The odds of response for someone receiving the Low Interest message are 1.19 times compared to that of someone receiving the control. We cannot say that the more specific (Second Best) branding message produces a different response rate than the more generic Low Interest message, but either one does better than the control.

\section{CONCLUSIONS}

This paper proposes that cross-basis subsegmentation is a cost-effective approach to customisation. The firm should sub-segment its customers in different ways using complementary basis variables, and create marketing contacts that are comprised of content determined by the various subsegments. For example, the introduction to a letter could be determined by the customer's recency and frequency, while recommendations could be determined by previous purchases. By creating contacts in this way, the company can produce many versions of a contact towards increasing 
response rates, without incurring the expense of creating completely different content for each version. This feature makes the crossed-basis approach more costefficient.

The results of a case study illustrate the logic of the approach and evaluate its effectiveness with three true experimental studies. The case study shows how factor and cluster analysis can be used to develop 'interest' sub-segments using transaction history of previous purchases. It also proposes a sub-segmentation based on recency and frequency. These subsegmentations are crossed to produce 28 versions of a marketing contact. Customers are randomly assigned to the customised and control versions of the contact. We show that this customisation significantly increases response rates for lapsed customers and new customers.

The experimental studies also attempts to investigate how a firm should customise contacts for customers about whom little is known because of inadequate previous transaction history. When a firm knows little about a customer, should it create a contact that 'labels' the customer by attempting to guess the interests of the customer, or should it send a one-size-fits-all contact. This study finds that the former approach (sending a customised contact) is preferred.

Experiment 1 demonstrated that the crossed-basis approach can increase response rates using a weak intervention (simple cover letter attached to a catalogue). We conjecture that more refined interventions will produce larger effect sizes. For example another marketing contact would be to develop specialty catalogues targeted at specific sub-segments. The tone, organisation, and contents for the 'MostlyMusic' catalogue would be designed specifically for members of this subsegment. In addition to music, the catalogue would contain a limited selection of history and home/living books that would appeal to these music lovers.
Cover letters and specialty catalogues are obvious contacts that improve the company's core business of selling books, CDs, and movies, but much more is possible. The idea is to start with the wants and needs of a particular set of customers and develop products and services possibly through partnerships — that satisfy these tastes. For example, the Mostly Music sub-segment is a list of names that is interested in classical and related genres of music. People with these interests do more than listen to CDs, and the company could develop other products and services to satisfy these needs. Building on its existing reputation for screening out the highest quality media, it could facilitate attending concerts in regions where Mostly Music customers have high concentrations. Or offer classical music tours to, for example, Salzburg. The act of creating products and services for a sub-segment of customers goes far beyond cross-selling customers, as recommendation agents do, and showcases the power of this approach. In addition to selling books and music, the company can enter the business of satisfying the more general classical musical needs of certain customers. As another example of this reasoning, consider Tesco, which leverages its brand name and knowledge of customers to enter other categories such as selling pet insurance and offering banking services. Sub-segmentation enables this transformation.

As we indicated in the introduction, the application of this approach is not limited to direct mail and internet applications. It will soon be possible to customise television advertisements for individual households. For example, consider an advertisement for a vacation resort in Florida. A demographic sub-segmentation could determine which 'views' of the hotel to feature in the ad. Families with small children would see the hotel pool, with children playing in the water while the parents are relaxing by the pool with a good book. Retired couples 
would see an older couple strolling along the hotel beach. Young singles would see young people engaging in the night life. A separate geographic sub-segmentation could feature customised information about getting to the resort. Those in the Boston market would see the lowest price of an economy flight and be told about the airport shuttle. Those in Atlanta would be told that the resort is an easy 4-hour drive from home. This approach could be combined with a recommendation agent to construct web pages with branding messages developed based on previous-purchasecategory sub-segments, incentives determined by customer lifetime value, and cross-sold items from a recommendation agent.

Customisation has strategic value beyond cross-selling customers more books, movies, music, or other stuff such as concerts and tours. It enables the company to be more relevant to its customers and bolster its brand reputation for identifying the highest quality media that interests certain consumers. Systematic customisation should help it to increase the trust and loyalty of its customers, which should produce desirable long-term effects such as increased protection from competition, consolidation of media purchases, and increased customer long-term value (of course, these are only conjectures). As spam-filters, pop-up blockers, caller-ID, digital recording systems, and other technologies designed to screen for unwanted advertisements proliferate, relevance and trust will become more important.

\section{References}

1 Adomavicius, G. and Tuzhilin, A. (2005) 'Toward the next generation of recommender systems: A survey of the state-of-the-art and possible extensions', IEEE Transactions on Knowledge and Data Engineering, Vol. 17, No. 6, pp. 734-749.

2 Humby, C. and Hunt, T. (2003) Scoring points: How Tesco is winning customer loyalty, Kogan Page, London.

3 Batra, R. (1999) 'Segmentation analysis', in: Shepard, D. (Ed.) The new direct marketing: How to implement a profit-driven database marketing strategy', McGraw-Hill, New York, pp. 288-301.

4 Rigby, D., Reichheld, F. and Schefter, P. (2002) 'Avoid the four perils of CRM', Harvard Business Review, Vol. 80, No. 2, pp. 101-109.

5 Malthouse, E. (2003) 'Database sub-segmentation', in: Iacobucci, and Calder (Eds.), Kellogg on Integrated Marketing, Wiley, New York, pp. 162-188.

6 Simonson, I. (2005) 'Determinants of Customers' Responses to Customized Offers: Conceptual Framework and Research Propositions', Journal of Marketing, Vol. 69 (January), pp. 32-45. 